\title{
sciendo
}

Folia Oeconomica Stetinensia

Volume 20 (2020) Issue 2

DOI: $10.2478 /$ foli-2020-0037
WYDZIAL NAUK EKONOMICZNYCH I ZARZAQDZANIA

\section{VALUE CO-CREATION AND VALUE CO-DESTRUCTION - A CASE OF ONLINE CONSUMPTION}

\author{
Katarzyna Dziewanowska, Ph.D., Associate Professor ${ }^{1}$ \\ Agnieszka Kacprzak, Ph.D., Associate Professor ${ }^{2}$ \\ Uniwersytet Warszawski \\ Wydziat Zarzadzania \\ Katedra Marketingu \\ Szturmowa 1/3, 02-678 Warszawa, Poland \\ 1e-mail: kdziewanowska@wz.uw.edu.pl \\ ORCID: 0000-0003-1897-0534 \\ ${ }^{2}$ e-mail: akacprzak@wz.uw.edu.p \\ ORCID: 0000-0003-1949-9131
}

Received 13 January 2020, Accepted 20 March 2020

\begin{abstract}
Research background: The paper focuses on value co-creation and co-destruction during online consumption. The current understanding of the concept of value is based on the premise that value emerges from interactions leading to exchange among multiple actors, including customers and companies. This implies the active role of all participants and leads to diversified outcomes, both positive (value co-creation) and negative (value co-destruction). The phenomenon of value co-destruction is studied in the context of online consumption, which is particularly suitable as it allows for consumer proactivity and participation in the process of exchange.

Purpose: The first purpose of the study is the conceptualization and operationalization of value co-creation and co-destruction. The second aim is to estimate the frequency of activities that can be conceptualized as various dimensions of online value co-creation/co-destruction.

Research methodology: The empirical part presents the results of an exploratory study based on a survey (PAPI) conducted on a sample of 212 university students.

Results: The main findings suggest that although young people regularly practice online consumption, they tend to behave in a rather passive manner and their value co-creation/co-destruction behaviours are limited to mostly price and promotion related activities.
\end{abstract}

Novelty: Value co-destruction is a recent and understudied phenomenon. This paper proposes a conceptualization and operationalization of a value co-destruction concept.

Keywords: value, co-creation, co-destruction, online consumption, young consumers

JEL classifications: M30, M31, M39, E20 


\section{Introduction}

There is no doubt that the rapid development of information technology brings about significant changes in our lives. The availability of computers and mobile devices, along with all-present access to the Internet is reflected in changing consumption patterns. More and more activities, such as shopping, entertainment and education, are performed online. This is accompanied by a change in both consumers and companies. The consumer has become a prosumer, who is willing to actively participate in certain processes, such as product/service design, sharing ideas and collaborating with companies and other consumers. In turn, companies offer a variety of platforms facilitating consumer participation and collaboration (Kotler, Kartajaya, Setiawan, 2017).

Value has been a key focus of both theoreticians and practitioners for several decades but now the understanding of this concept has changed (Gallarza, Gil-Saura, Holbrook, 2011). Value is no longer to be offered by companies, but it emerges from the collaborative effort of various actors (including companies and customers). This process can lead to either positive (co-creation) or negative (co-destruction) outcomes for its participants (Plé, Cáceres, 2010). The online environment offers unprecedented opportunities for customer participation in value formation, however both positive and negative aspects of this process can be observed.

In this paper we propose the conceptualization and preliminary operationalization of value co-creation and co-destruction for online consumption. The results of the exploratory research estimating the frequency of these activities is also presented.

\section{Literature review}

\subsection{The concept of value and the process of value co-creation and co-destruction}

Value is a phenomenon that has remained in the centre of attention of researchers and practitioners of marketing for decades (Gallarza, et al., 2011). Its importance is also reflected in the current definition of marketing provided by the American Marketing Association (AMA, 2013). The recent emergence of the service-dominant logic (SDL) in marketing (Vargo, Lusch, 2004; Vargo, Lusch, 2008) has put value and the process of value formation in the spotlight. Value is defined broadly as a change in the viability (well-being) of a system (Vargo, Vargo, Akaka, Vaughan, 2017) and it cannot be simply delivered/created by a company. In fact, the company can only offer a proposition of value, which will be subjectively determined by the consumer via the experience of the co-creation process (Lusch, Vargo, Wessels, 2008). 
Moreover, value is a phenomenon closely connected with the customer experience which is an enabler of value creation (Holbrook, 1999). Similarly, both concepts are multidimensional and of a phenomenological nature (Pine, Gilmore, 2011; Vargo, et al., 2017).

The concept of value co-creation was introduced by Prahalad and Ramaswamy (2004) and it gained popularity with the development of the SDL concept (Vargo, Lusch, 2004). The literature on the subject offers numerous definitions that emphasize experiential aspects (Prahalad, Ramaswamy, 2000, 2004), customer participation and engagement (Gebauer, Johnson, Enquist, 2010) and interactions (Ranjan, Read, 2016). Value co-creation can be defined as "an extended in time process that can occur in any phase of customer decision-making process, during and after consumption, in which actors voluntarily engage in direct and indirect interactions based on use and exchange of resources leading to mutual benefits" (Dziewanowska, 2018, p. 72). It is worth noting that the term 'actors' refers to all participants of the process, i.e. customers, companies, intermediaries, etc.

There is an ample body of research on customer value co-creation and most studies focus on its positive outcomes (Plé, Cáceres, 2010). However, given the phenomenological nature of value, the interactions and exchange among actors may not always lead to positive results. In fact, the cooperation is not always seamless as its participants can lie (Harris, Daunt, 2011), be verbally violent (Rafaeli et al., 2012), complain without reason (Wirtz, McCollKennedy, 2010) and exhibit strong negative emotions (McColl-Kennedy, Patterson, Smith, Brady, 2009). This dysfunctional behavior is a fairly new area of research in marketing and can be defined as any behavior that impairs the process of value co-creation (Greer, 2015).

Recently, negative value co-creation has been gaining popularity and it is referred to as value co-destruction (Plé, Cáceres, 2010; Echeverri, Skåéln, 2011) or defective co-creation (Greer, 2015). Plé and Cáceres (2010, p. 431) define value co-destruction as "an interactional process between service systems that results in a decline in at least one of the systems' well-being" and suggested that this process occurs due to the misuse (accidental or intentional) of available resources. Moreover, Smith (2013) studied value co-destruction from the customer's perspective of resource loss and misuse. She observed that the primary loss of resources (e.g. monetary and hedonic ones) is followed by a secondary loss of resources (e.g. emotional and time-related) resulting in the development of "cycles" or "spirals" that negatively impact on actors/system well-being (Smith, 2013, pp. 1889). According to Echeverri and Skåéln (2011) the interactions among actors have to be accompanied by the congruence of the procedures, understandings and engagements for the co-creation to occur. However, since the whole process is interactive and dynamic, the initial congruence may still lead to reductive value formation while initial 
incongruence may be followed by recovery value co-formation. Interestingly, the outcome of the interactive value formation process can also result in a "neutral" or "indifferent" outcome identified as value no-creation by Makkonen and Olkkonen (2017) It also should be noted that whether value is co-created or co-destructed depends on the perspective within a system. Therefore, each case of value formation has multiple possible assessments (Vargo, et al., 2017).

\subsection{Value co-creation and co-destruction in the online environment - conceptual dimensions and indicators}

Value co-creation and co-destruction are relatively understudied concepts in the online environment, which is particularly true for the latter one. Although value co-creation has been studied in such contexts as online communities (Chen, Drennan, Andrews, Hollebeek, 2018), customer loyalty (Chen, Wang, 2016; Van Oerle, Lievens, Mahr, 2018) shopping behaviour (Liu, Luo, 2019), studies on value co-destruction are rare and they focus on marketing communication e.g. writing online reviews (Zhang, Lu, Torres, Chen, 2018), (mis)use of resources (Robertson, Polonsky, McQuilken, 2014) and brand experience (Quach, Thaichon, 2017).

In turn, our paper focuses on five dimensions of the marketing-mix pointing out to possible indicators of value co-creation and co-destruction in these areas. The aim of this exploratory study is to estimate the frequency of certain behaviours of internet users that may be conceptualized as value co-creation or co-destruction. This study is also the first step towards constructing a scale to measure co-destruction and co-creation in the online environment.

As can be seen in Table 1, the possible indicators of online value co-creation comprise such behaviours as designing by oneself a product ordered online (product) or uploading instructional videos/posts about products/services that can be ordered online (promotion)). In turn, value codestruction may manifest itself for example in being absent at home at the date agreed with the courier (place) or being rude to helpline/chat staff when unsatisfied with the service (people). 
Table 1. The possible indicators of value co-creation and co-destruction for online consumption

\begin{tabular}{|c|c|c|}
\hline $\begin{array}{l}\text { Marketing- } \\
\text {-mix }\end{array}$ & Value co-creation & Value co-destruction \\
\hline Product & $\begin{array}{l}\text { - designing a product ordered online by oneself, } \\
\text { - taking part in the online testing of products/ } \\
\text { services, } \\
\text { - } \text { submitting new products/services ideas to } \\
\text { companies, } \\
\text { - informing companies about the possibilities } \\
\text { of improving their products or services, } \\
\text { - } \text { assembling products ordered online, } \\
\text { - } \text { making suggestions to the company about } \\
\text { improving customer service }\end{array}$ & $\begin{array}{l}\text { - damaging the product due to improper use, } \\
\text { - } \text { ordering the wrong product because of not } \\
\text { reading the description carefully }\end{array}$ \\
\hline Place & $\begin{array}{l}\text { - } \text { ordering products online with pickup from the } \\
\text { seller, } \\
\text { - ordering products online with delivery to } \\
\text { a parcel machine or pickup point }\end{array}$ & $\begin{array}{l}\text { - being rude to the courier whose services were } \\
\text { not acceptable, } \\
\text { - being not at home on the date of the delivery, } \\
\text { - not picking up a package paid on delivery }\end{array}$ \\
\hline Price & $\begin{array}{l}\text { - participating in online auctions, } \\
\text { - using daily deals services, } \\
\text { - hunting for online bargains }\end{array}$ & $\begin{array}{l}\text { - not admitting that the price was miscalculated } \\
\text { in your favour, } \\
\text { - not paying for the auctioned product, } \\
\text { - being late with payment for the purchased } \\
\text { product, } \\
\text { - purposefully damaging the product to get } \\
\text { compensation }\end{array}$ \\
\hline Promotion & $\begin{array}{l}\text { - informing other people about bargains found } \\
\text { online, } \\
\text { - sharing opinions about purchased products and } \\
\text { services during discussions with other internet } \\
\text { users, } \\
\text { - answering other customers' questions about } \\
\text { products/services that can be ordered online, } \\
\text { - taking part in contests organized by companies } \\
\text { on the internet, } \\
\text { - posting tutorials/posts about products/services } \\
\text { that can be ordered online }\end{array}$ & $\begin{array}{l}\text { - regretting not having read online reviews } \\
\text { before purchasing the product/service, } \\
\text { - uploading photos/videos with examples } \\
\text { of defective products/services to the internet, } \\
\text { - posting negative opinions about a product/ } \\
\text { service in several different places so that it can } \\
\text { reach more people, } \\
\text { - discourage other internet users from using the } \\
\text { product/service, } \\
\text { - focusing on emotions rather than facts when } \\
\text { writing negative comments about products/ } \\
\text { services, } \\
\text { - writing negative reviews about a company's } \\
\text { small shortcomings, } \\
\text { - criticizing online other people who write about } \\
\text { products/services }\end{array}$ \\
\hline People & $\begin{array}{l}\text { - contact the company directly in the case } \\
\text { of dissatisfaction with products/services } \\
\text { purchased online }\end{array}$ & $\begin{array}{l}\text { - being rude to helpline/chat staff when you are } \\
\text { dissatisfied with the service, } \\
\text { - intentionally misleading a company's } \\
\text { employee, } \\
\text { - assessing negatively an employee to take } \\
\text { revenge on the company }\end{array}$ \\
\hline
\end{tabular}

Source: own elaboration. 


\section{Data and method}

This explanatory study used a paper-and-pencil interview (PAPI) technique (Churchill, 1995) on a convenient sample of 212 undergraduate and graduate management students from a large university located in a city above 1 million inhabitants. The rationale for choosing young consumers as the study subject is that they spend a lot of time online and often engage in online consumption activities. Our research sample consists of $68 \%$ women and $32 \%$ men; the mean for age is 22.67 . Nearly half of the respondents (49\%) declare to spend 3-5 hours online, while $41 \%$ spend more than 6 hours and only $10 \%$ declare that they spend less than 2 hours a day online. As for the frequency of online shopping, 38\% of the study participants purchase products/services several times a month, followed by $25 \%$ who do online shopping once a month and a further $25 \%$ do it several times a year. Only $8.5 \%$ of the respondents do online shopping at least several times a week, while $4 \%$ of the respondents have little experience with online shopping (buying once a year). No person declared not having any experience with online shopping.

The survey questionnaire comprises 19 items for value co-creation and 19 items for value co-destruction with a frequency scale (very often, often, sometimes, rarely, never). 10 items with a 5-point semantic differential scale were also included to investigate respondents' preferences in terms of active/passive participation in online consumption.

Data were analysed with the use of IBM SPSS Ver. 26.0. The statistical analysis included: frequencies, correlations and non parametric tests

\section{Research results}

As can be seen in figure 1, the most common indicators of online value co-creation are those connected with price dimension of the marketing-mix, such as hunting for online bargains ( $98 \%$ of respondents declared this behaviour) or informing other people about promotions found online (94\%). These are followed by two behaviours from the distribution dimension, which in fact are also price-related, that is ordering products online with delivery to a parcel machine or pickup point (94\%) and ordering products online with pickup from the seller (86\%). The least popular form of value co-creation was the most engaging one - only $8 \%$ of study participants declare that they post video/text tutorials about products/services that can be ordered online. 


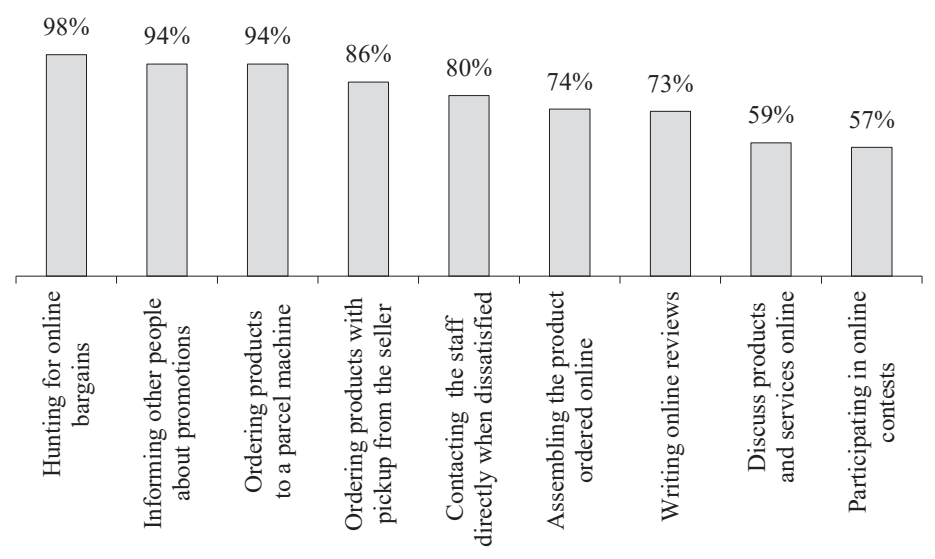

Figure 1. Indicators of online value co-creation declared by more than $50 \%$ of the sample Source: own research.

The frequency of value co-creation behaviours is correlated with online shopping frequency. The more experience with e-shopping, the more frequent participation in value cocreation is reported. The positive correlation with online shopping frequency was found for testing new products $(\mathrm{r}=0.139 ; \mathrm{p}<0.05)$, assembling products $(\mathrm{r}=0.192, \mathrm{p}<0.01)$, choosing delivery to parcel machines $(r=0.329, p<0.01)$, hunting for online bargains $(r=0.235, p<0.01)$, writing reviews $(\mathrm{r}=0.272, \mathrm{p}<0.01)$, discussing products and services with other Internet users $(r=0.202, p<0.01)$, contacting the company directly in case of dissatisfaction $(r=0.220$, $\mathrm{p}<0.01)$ and answering other customers questions about products and services $(r=0.204$, $\mathrm{p}<0.01)$. Another variable influencing the frequency of some of the indicators of value cocreation is gender. According to our study, female participants are more eager to inform other people about online bargains $\left(\chi^{2}=9.967, \mathrm{df}=4, \mathrm{p}=0.41\right)$, while male respondents more often submit ideas about new products/services to companies $\left(\chi^{2}=13.287\right.$, df $\left.=4, p=0.004\right)$ and participate in online auctions $\left(\chi^{2}=15.346, \mathrm{df}=4, \mathrm{p}=0.004\right)$.

Figure 2 presents the most frequently declared indicators of value co-destruction. In this case, only 5 of the 19 listed indictors passed the 50\% respondent declaration threshold. The most popular one is product damage due to improper use $(87 \%$ of respondents reported such behaviour). The respondents also quite commonly regret not having read online reviews before online purchases (71\%) and admit to being absent at home at the pre-arranged delivery time $(70 \%)$. The least popular online activities leading to value co-destruction include damaging a product in order to get compensation (only $4 \%$ of the respondents report this behaviour) and failing to pay for auctioned products $(4 \%)$. 


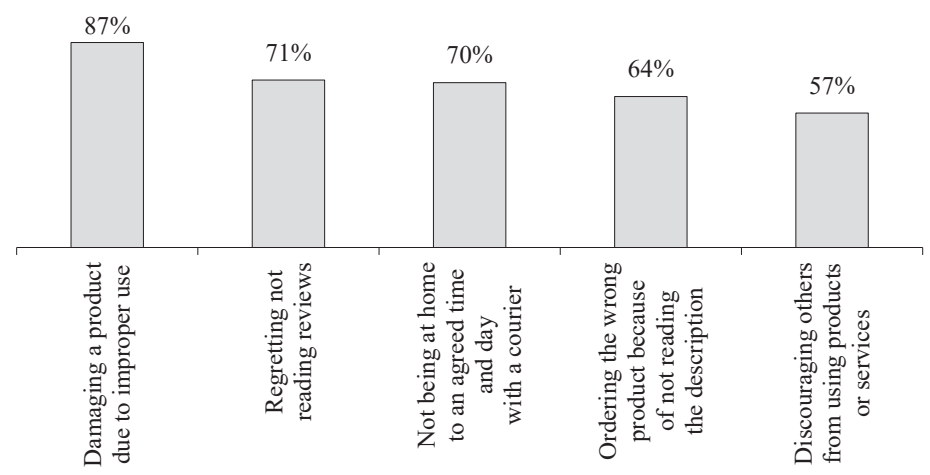

Figure 2. Indicators of online value co-destruction declared by more than $50 \%$ of the sample Source: own research.

Similarly to value-co-creation also certain indicators of value co-destruction are correlated with frequency of online shopping, namely: being absent at the delivery date $(r=0.189$, $\mathrm{p}<0.01)$, not paying for auctioned products $(\mathrm{r}=0.166, \mathrm{p}<0.05)$, uploading photos/videos with examples of defective products/services $(r=0.145, \mathrm{p}<0.05)$, posting negative opinions about the product/service in several different places $(r=0.175, \mathrm{p}<0.05)$ and discouraging other Internet users from using the product/service $(r=0.143, \mathrm{p}<0.05)$. Interestingly, gender appears to influence the frequency of negative behaviours toward other people. Female respondents report being rude to helpline/chat staff when dissatisfied with a service more often than men $\left(\chi^{2}=10.975, \mathrm{df}=4, \mathrm{p}=0.027\right)$. In turn, male study participants more frequently intentionally mislead a company's employee $\left(\chi^{2}=11.677, \mathrm{df}=4, \mathrm{p}=0.009\right)$, and criticize online other people who write about products/services $\left(\chi^{2}=9.547, \mathrm{df}=4, \mathrm{p}=0.049\right)$.

Table 2 presents the means for semantic differentials scales. Customer active behaviour is presented on the left, while items on the right refer to more passive behaviour. Only in 4 cases out of 10 are the respondents inclined towards more active participation in value co-creation. Two of them are connected with price (actively looking for the best price and informing others about bargains) and one with avoiding contact with real people when looking for product/service information and browsing the Internet instead. 
Table 2. Semantic differential between active engagement in online value co-creation and passive behaviour

\begin{tabular}{|c|c|c|c|c|c|c|}
\hline \multirow{2}{*}{$\begin{array}{l}\text { Active engagement } \\
\text { in value co-creation }\end{array}$} & -2 & -1 & 0 & 1 & 2 & \multirow{2}{*}{ Passive behaviour } \\
\hline & \multicolumn{5}{|c|}{$\%$} & \\
\hline Assembling a product by oneself & 4 & 10 & 22 & 26 & 38 & Buying an assembled product \\
\hline Picking up a delivery out of home & 10 & 19 & 21 & 14 & 36 & Waiting for a delivery at home \\
\hline Participating in auctions & 2 & 5 & 13 & 25 & 55 & Buying products at set prices* \\
\hline Negotiating a price with the seller & 7 & 13 & 23 & 26 & 32 & Paying the price set by the seller* \\
\hline Payment in advance & 41 & 13 & 24 & 9 & 13 & Payment on delivery* \\
\hline $\begin{array}{l}\text { Putting effort into finding an } \\
\text { attractive price }\end{array}$ & 38 & 30 & 18 & 9 & 6 & Fast purchase at a regular price* \\
\hline $\begin{array}{l}\text { Sharing opinions about products } \\
\text { with others }\end{array}$ & 9 & 24 & 30 & 23 & 16 & Keeping your opinion(s) to yourself* \\
\hline $\begin{array}{l}\text { Writing public reviews of products/ } \\
\text { services }\end{array}$ & 3 & 7 & 16 & 25 & 49 & Sharing your opinion(s) privately \\
\hline $\begin{array}{l}\text { Informing other people about } \\
\text { bargains }\end{array}$ & 26 & 38 & 20 & 11 & 5 & $\begin{array}{l}\text { Keeping information about bargains } \\
\text { to yourself }\end{array}$ \\
\hline $\begin{array}{l}\text { Browsing the Internet to find } \\
\text { information about a product/service }\end{array}$ & 56 & 26 & 11 & 5 & 2 & $\begin{array}{l}\text { Contacting staff to get information } \\
\text { about products/services }\end{array}$ \\
\hline
\end{tabular}

Source: own research.

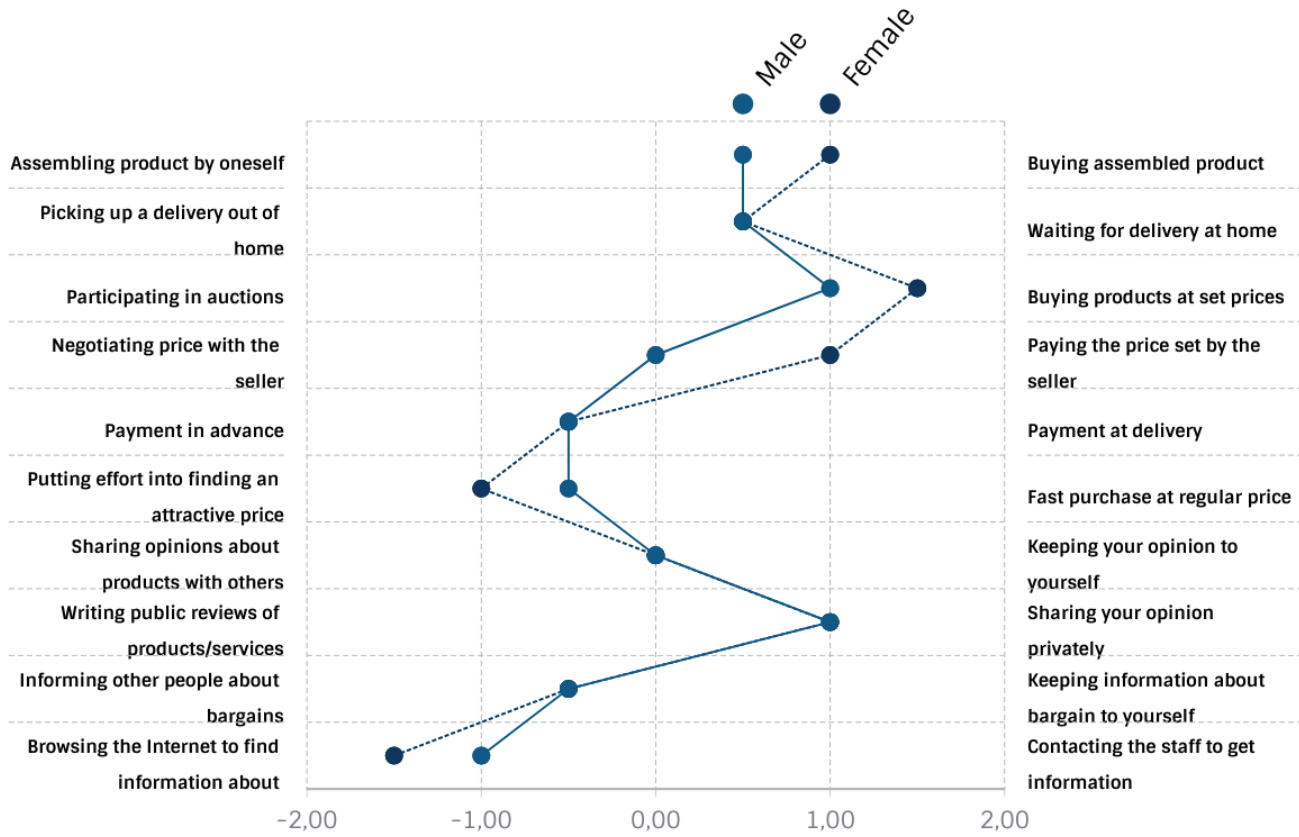

Figure 3. Gender differences in active engagement in online value co-creation

Source: own research. 
Statistically significant differences between male and female respondents were found for participating in an auction $\left(\chi^{2}=9.516, \mathrm{df}=4, \mathrm{p}=0.049\right)$ and negotiating a price with a seller $\left.\chi^{2}=13.417, \mathrm{df}=4, \mathrm{p}=0.009\right)$. Both of these active behaviours are more common for men than women. Figure 3 presents a snake chart for gender differences in active engagement in online value co-creation. In turn, frequency of online shopping is positively correlated with writing public reviews $(r=0.176, p<0.05)$ and paying in advance $(r=0.182, p<0.05)$.

\section{Conclusions}

The results of the study presented above allow for several preliminary conclusions. Firstly, it should be noted that the respondents more readily engage in value co-creation rather than co-destruction practices. Among the first ones, the most common practices are connected with less active behaviours in the area of price, promotion and distribution. Interestingly, value codestruction seems to occur most often in the product area and communication. It refers mostly to the misuse of resources (Robertson, et al., 2014), such as damaging the product due to improper use and not reading the description prior to placing an order. Such behaviour seems to result from a certain passivity in consumers' approach to online experiences when they decide not to perform an activity (e.g. not to read an instruction, not to be present during the set time of a delivery). Interestingly, some of these co-destructive behaviours may differently impact the company and the consumer which emphasizes the subjectivity of value co-creation/codestruction (Vargo, Akaka, Vaughan, 2017). The behaviour when the consumer does not pick up the parcel sent by the company can result in 'no value' output from the consumer's perspective and value co-destruction for the company (Makkonen, Olkkonen, 2017).

It can be observed that young respondents in this study choose a fairly passive approach to online consumption and prefer stable and safe practices, such as purchasing ready-made products at set prices. This preference of passive experiences is in line with a general tendency in Polish society, although it is typically less popular among younger than older consumers (Kacprzak, Dziewanowska, Skorek, 2016). At the same time, they use the Internet to find information and best deals and willingly share these findings with other customers.

This study is not without its limitations. Firstly, it is exploratory in nature and was conducted on a non-representative sample of respondents, who are business students. Such a sample is rather homogeneous and specific; thus the results cannot be generalized for the whole population. Also, it is based on respondents' declarations and therefore it may not reflect actual behaviours. Especially the items measuring value co-destruction were related to sensitive 
issues and therefore the respondents' answers might not be accurate. Based on these preliminary results, as a next step to research, the scale for measurement value co-destruction and value co-creation can be proposed.

\section{References}

AMA (2013). American Marketing Association. Retrieved from: https://www.ama.org/AboutAMA/Pages/Definition-of-Marketing.aspx (3.10.2016).

Chen, C.-F., Wang, J.-P. (2016). Customer participation, value co-creation and customer loyalty - A case of airline online check-in system. Computers in Human Behavior, 62 (9), 346-352. DOI: 10.1016/j.chb.2016.04.010.

Chen, T., Drennan, J., Andrews, L. Hollebeek, L.D. (2018). User experience sharing: understanding customer initiation of value co-creation in online communities. European Journal of Marketing, 52 (5-6), 1154-1184. DOI: 10.1108/EJM-05-2016-0298.

Churchill, G. (1995). Marketing Research: Methodological Foundations. 6th Edition. San Diego: Hartcourt College Publishers

Dziewanowska, K. (2018). Współtworzenie wartości w marketingu. Przykład szkolnictwa wyższego. Warszawa: C.H. Beck.

Echeverri, P., Skåéln, P. (2011). Co-creation and co-destruction: A practice-theory based study of interactive value formation. Marketing Theory, 11 (3), 351-373. DOI: $10.1177 / 1470593111408181$.

Gallarza, M.G., Gil-Saura, I., Holbrook, M.B. (2011). The value of value: Further excursions on the meaning and role of customer value. Journal of Consumer Behaviour, 10 (4), 179191. DOI: $10.1002 / \mathrm{cb} .328$.

Gebauer, H., Johnson, M., Enquist, B. (2010). Value co-creation as a determinant of success in public transport services: a study of the Swiss Federal Railway operator (SBB). Managing Service Quality: An International Journal, 20 (6), 511-530. DOI: 10.1108/ 09604521011092866.

Greer, D.A. (2015) Defective co-creation. Developing a typology of consumer dysfunction in professional services. European Journal of Marketing, 49 (1/2), 238-261. DOI: 10.1108/ EJM-07-2012-0411.

Harris, L.C., Daunt, K.L. (2011). Deviant customer behaviour: a study of techniques of neutralisation. Journal of Marketing Managemen, 27 (7-8), 834-853. DOI: 10.1080/ $0267257 X .2010 .498149$. 
Holbrook, M. (1999). Consumer Value. A Framework for Analysis and Research. London: Routledge.

Kacprzak, A., Dziewanowska, K., Skorek, M. (2016). Gospodarka doświadczeń-perspektywa polskiego konsumenta. Warszawa: Wydawnictwo Naukwe PWN.

Kotler, P., Kartajaya, H., Setiawan, I. (2017). Marketing 4.0. Warszawa: MT Biznes.

Liu, Y., Luo, X. (2019). Customer value co-creation behavior effects on online purchase intention. Journal of Advanced Computational Intelligence and Intelligent Informatics, 23 (2), 252-260.

Lusch, R.F., Vargo, S.L., Wessels, G. (2008). Toward a conceptual foundation for service science: Contributions from service dominant logic. IBM Systems Journal, 47 (1), 5-14.

Makkonen, H., Olkkonen, R. (2017). Interactive value formation in interorganizational relationships: Dynamic interchange between value co-creation, no-creation, and co-destruction. Marketing Theory, 17 (4), 517-535. DOI: 10.1177/1470593117699661.

McColl-Kennedy, J.R., Patterson, P.G., Smith, A.K., Brady, M.K. (2009). Customer rage episodes: emotions, expressions and behaviors. Journal of Retailing, 85 (2), 222-237. DOI: 10.1016/j.jretai.2009.04.002.

Pine, B.J., Gilmore, J.H. (2011). The Experience Economy. Boston: Harvard Business Review Press.

Plé, L., Cáceres, R.C. (2010). Not always co-creation: introducing interactional co-destruction of value in service-dominant logic. Journal of Services Marketing, 24 (6), 430-437. DOI: 10.1108/08876041011072546.

Prahalad, C.K., Ramaswamy, V. (2000). Co-opting customer competence. Harvard Business Review, 78 (1), 79-90.

Prahalad, C.K., Ramaswamy, V. (2004). Co-creation experiences: The next practice in value creation. Journal of Interactive Marketing, 18 (3), 5-14. DOI: 10.1002/dir.20015.

Quach, S., Thaichon, P. (2017). From connoisseur luxury to mass luxury: Value co-creation and co-destruction in the online environment. Journal of Busines Research, 81, 163-172, DOI: 10.1016/j.jbusres.2017.06.015.

Rafaeli, A., Erez, A., Ravid, S., Derfler-Rozin, R., Efrat Treister, D., Scheyer, R. (2012). When customers exhibit verbal aggression, employees pay cognitive costs. Journal of Applied Psychology, 97 (5), 931-950. DOI: 10.1037/a0028559.

Ranjan, K.R., Read, S. (2016). Value co-creation: concept and measurement. Journal of the Academy of Marketing Science, 44 (3), 290-315. DOI:10.1007/s11747-014-0397-2.

Robertson, N., Polonsky, M., McQuilken, L. (2014). Are my symptoms serious Dr Google? A resource-based typology of value co-destruction in online self-diagnosis. Australasian Marketing Journal, 22 (3), 246-256. DOI: 10.1016/j.ausmj.2014.08.009. 
Smith, A.M. 2013. The value co-destruction process: a customer resource perspective. European Journal of Marketing, 47 (11/12), 1889-1909. DOI:10.1108/EJM-08-2011-0420.

Van Oerle, S., Lievens, A., Mahr, D. (2018). Value co-creation in online healthcare communities: The impact of patients' reference frames on cure and care. Psychology \& Marketing, 35 (9), 629-639. DOI: 10.1002/mar.21111.

Vargo, S.L., Akaka, M.A., Vaughan, C.M. (2017). Conceptualizing Value: A service-ecosystem view. Journal of Creating Value, 3 (2), 117-124. DOI: 0.1177/2394964317732861.

Vargo, S.L., Lusch, R.F. (2008). Service-dominant logic: continuing the evolution. Journal of the Academy of Marketing Science, 3 6(1), 1-10. DOI: 10.1007/s11747-007-0069-6.

Vargo, S., Lusch, R. (2004). Evolving to a New Dominant Logic for Marketing. Journal of Marketing, 68 (1), 1-17. DOI: 10.1509/jmkg.68.1.1.24036.

Wirtz, J., McColl-Kennedy, J.R. (2010). Opportunistic customer claiming during service recovery. Journal of the Academy of Marketing Science, 38 (5), 645-675. DOI: 10.1007/ s11747-009-0177-6.

Zhang, T., Lu, C., Torres, E., Chen, P.-J. (2018). Engaging customers in value co-creation or co-destruction online. Journal of Services Marketing, 32 (1), 57-69. DOI: 10.1108/JSM01-2017-0027. 